\title{
Job Satisfaction among Nurses Working Medical Teaching Institutions Khyber Pakhtunkhwa
}

\author{
Abdullah $^{1^{*}, \text { Fatheur Rahman }^{2} \text {, Hassan } \text { Ali }^{3} \text {, Javid Iqbal }}{ }^{4}$ \\ ${ }^{1} B S N, M P H, R N$ Officer Health Department KPK \\ ${ }^{2} B S N$, MSN, RN Officer Health Department KPK \\ ${ }^{3}$ BSC. N, RN Officer Health Department KPK \\ ${ }^{4}$ Dip N. MPH, RN Officer Health Department KPK
}

*Corresponding Author: Abdullah BSN, MPH (RN Officer Health Department KPK), Pakistan. Email: aurang.zeb@rmi.edu.pk

\begin{abstract}
Background: Job satisfaction is very important factor for an organization to retain the employees. Job satisfaction is also important for nurses because nurses are the back bone of hospital.
\end{abstract}

Objectives: To know the job satisfaction of Medical Teaching Institution (MTI) Nurses working in Ayub Teaching Hospital.

Methodology: A simple cross sectional study design was used and data was collected in Ayub Teaching Hospital Abbottabad through a self-administered questionnaire, the sample was calculated through "WHO sample size calculator" which was 80.

Results: Overall $83 \%$ respondents were satisfied from their job, and $64 \%$ from salary. Job security is the main reason for dissatisfaction.

Conclusion: From this study it has been concluded that most of the nurses were satisfied from their job but the main thing which can hinder their satisfaction level is the job security.

Keywords: MTI (Medical Teaching Institution). ATD (Abbottabad).

\section{INTRODUCTION AND BACKGROUND}

Job satisfaction is important factor for nurses because nurses are the back bone of hospital. It can be defined by Cambridge English dictionary as 'the feeling of pleasure and achievement that you experience in your job when you know that your work gives you this feeling'. Job satisfaction is very much related to good productivity and performance. As the responsibility of nurses is increased now a days because the major tertiary care hospital of KPK become Medical Teaching Institution (MTI) means they got autonomy. According to Medical Teaching Institution reforms bill (2015), Medical Teaching Institution means a Medical College, Dental College, or other health related teaching institutions and their affiliated teaching hospitals in the public sector or directly under the control of Government, which provides healthcare services, medical education and training, and medical research. Due to this it is needed to know the job satisfaction of nurses working in Ayub teaching Hospital. A very little work has been done on job satisfaction among nurses but no work is done on Medical Teaching Institution (MTI), previously.

In the study of Habit Akhtar Bahalkani et al (2011) most of staff is not satisfied from their job due to so many reason like responsibility, work environment, benefits etc. One of the study in Karachi in 2013 suggested that healthcare professionals must be given attractive compensation, opportunities for career development and promotions ${ }^{4}$, The results of this study have evaluated that the job satisfaction in healthcare professionals is highly associated with some factors which need to be developed and focused by the healthcare management. In a same study of tertiary care hospitals of Rawalpindi (Abida Sultana et al, 2011) show that only $12.8 \%$ of nurses are satisfied from their job in government setup. 
Nurses are always seems to be overburden and no such response are given to them in accordance to their tough job. Job satisfaction is a feeling of fulfillment or enjoyment that a person derives from their job. According to the study of Khan a et al (2012) the greatest level of satisfaction of employees can bring best results for organization. Job satisfaction is very much related to good productivity and performance. Job satisfaction is very important for every worker especially for nurses because they are the back bone of health care system. A study of factor related to job satisfaction of nurses in Albania concluded that majority of the young and highly educated nurses are less satisfied. Similar result was found in the study of Lorber $M$ and Savič B.S (2012). In the study of Bahalkaniet almost of staff is not satisfied from their job due to so many reasons like responsibility, work environment, benefits etc. These factors highly affect job satisfaction. A study was done in Pakistan by Naveed I et al (2016) which find that the main reason which affects job satisfaction is the negligence in making hospital policies. Nurses always seem to be overly burdened and no such response is paid to them in accordance to their tough job.

The study of Khan A.et all shows that there are so many factor which effect the job satisfaction of nursing staff which includes pay, promotion, job security and work environment. Another study of Pakistan by Dar I.S, Ahsan-ul-Haq M \& Quratulain (2015) show that factors influencing job satisfaction of nurses has identified that $60 \%$ of nurses are dissatisfied from their salaries in public sector. It means that salary affects the job satisfaction of any worker. Reward and good relationship with colleagues are factor which affect the job satisfaction of nurses (Jaiswal et al 2015). It should be kept in mind that job satisfaction level affects not only the quality of the functions provided by the nurse, but also satisfaction of patient is very important for health care institutions to measure these perceptions by the nurses (Zahaj $\mathrm{M}$ et al, 2016). Wang Yetal (2015) had found that the practice environment is most influential factor on job satisfaction. As the job satisfaction highly affect nurses and very little work has Table1 been done on job satisfaction among nurses in Pakistan especially in Khyber Pakhtunkhwa.

\section{MeTHODOLOGY}

\subsection{Objective of the Study}

To know the job satisfaction of MTI Nurses working in Ayub Teaching Hospital.

\subsection{Consent form and Confidentiality}

Consent form was attached to the questionnaire for participant's agreement and also it was written in consent form that the information of participants will be kept confidential and only used for academic purpose.

\section{Materials \& Methods}

- Study Design: A descriptive cross sectional study was used in this research.

- Study Population/Setting: This study was conducted on nurses working in Ayub Teaching Hospital Abbott bad, which is a tertiary care hospital and the government of Khyber Pakhtunkhwa nominated it one of the medical teaching institution.

- Sample Size and Sampling Technique: A sample random sampling technique was used in this study in which the total number of sample size was calculated through WHO sample size calculator which was 80 .

- Including and Excluding Criteria: Only MTI nurses working in this hospital was included.

- Data Collection: Data was collected through a self administered questionnaire from nurses.

- A total number of 73 questionnaires were returned amongst 80 participants.

- Data Analysis Procedure: Data were analyzed by using SPSS version 16 and Microsoft excel.

\section{Results}

Out of 80 participants the respondent ratio was $91 \%$ in which $21.9 \%$ male and $78.1 \%$ female respondent (Table 1). Most of the respondent was in between 26 to 30 year of age. (Table 2)

\begin{tabular}{|l|l|l|}
\hline Gender & \multicolumn{1}{|c|}{ Frequency } & \multicolumn{1}{c|}{ Percent } \\
\hline Male & 16 & 21.9 \\
\hline Female & 57 & 78.1 \\
\hline Total & 73 & 100.0 \\
\hline
\end{tabular}


Table2: Age wise data (Categories)

\begin{tabular}{|l|l|l|}
\hline \multicolumn{1}{|c|}{ Age Categories } & \multicolumn{1}{c|}{ Frequency } & \\
\hline $20-25$ & 24 & 32.9 \\
\hline $26-30$ & 38 & 52.1 \\
\hline $31-35$ & 8 & 11.0 \\
\hline above 35 & 3 & 4.1 \\
\hline Total & 73 & 100.0 \\
\hline
\end{tabular}

Table3: Detailed of each variable wise result are given below.

\begin{tabular}{|l|l|l|l|l|l|l|}
\hline \multicolumn{2}{|l|}{ V=1 } & \multicolumn{2}{l|}{ Are you satisfied from your current job? } & \multirow{2}{*}{ Total } \\
\hline & Mes & $\%$ & No & $\%$ & \\
\hline & Male & 14 & 19.2 & 2 & 2.7 & 16 \\
\cline { 2 - 6 } & Female & 47 & 64.4 & 10 & 13.7 & 57 \\
\hline
\end{tabular}

\begin{tabular}{|l|l|l|l|l|l|}
\hline & & \multicolumn{2}{|c|}{ Are you satisfied from the current salary giving to you? } & \multirow{2}{*}{ Total } \\
\hline & \multirow{3}{*}{ Male } & V=2 & Yes & No & \\
\hline & Count & 15 & 1 & 16 \\
\cline { 2 - 5 } & $\%$ of Total & $20.5 \%$ & $1.4 \%$ & $21.9 \%$ \\
\cline { 2 - 5 } & \multirow{2}{*}{ Female } & Count & 32 & 25 & 57 \\
\cline { 2 - 5 } & $\%$ of Total & $43.8 \%$ & $34.2 \%$ & $73.1 \%$ \\
\hline
\end{tabular}

\begin{tabular}{|l|l|l|l|l|l|}
\hline & & & \multicolumn{2}{|l|}{ Is Your job secure? } & \multirow{2}{*}{ Total } \\
\hline & & $\mathbf{V}=\mathbf{3}$ & Yes & No & \\
\hline \multirow{3}{*}{ Male } & Count & 13 & 3 & 16 \\
\cline { 3 - 6 } & & $\%$ of Total & $17.8 \%$ & $4.1 \%$ & $21.9 \%$ \\
\cline { 3 - 6 } & \multirow{2}{*}{ Female } & Count & 23 & 34 & 57 \\
\cline { 3 - 5 } & & $\%$ of Total & $31.5 \%$ & $46.6 \%$ & $78.1 \%$ \\
\hline \multirow{2}{*}{ Total } & Count & 36 & 37 & 73 \\
\cline { 2 - 5 } & & $\%$ of Total & $49.3 \%$ & $50.7 \%$ & $100.0 \%$ \\
\hline
\end{tabular}

\begin{tabular}{|c|c|c|c|c|c|}
\hline & $V=4$ & & \multicolumn{2}{|c|}{ Are any training given to you in this Hospital? } & \multirow[t]{2}{*}{ Total } \\
\hline & & & Yes & No & \\
\hline \multirow[t]{4}{*}{ Gender } & \multirow[t]{2}{*}{ Male } & Count & 1 & 15 & 16 \\
\hline & & $\begin{array}{ll}\% & \text { of } \\
\text { Total }\end{array}$ & $1.4 \%$ & $20.5 \%$ & $21.9 \%$ \\
\hline & \multirow[t]{2}{*}{ Female } & Count & 40 & 17 & 57 \\
\hline & & $\begin{array}{l}\% \\
\text { Total of }\end{array}$ & $54.8 \%$ & $23.3 \%$ & $78.1 \%$ \\
\hline \multirow{2}{*}{\multicolumn{2}{|c|}{ Total }} & Count & 41 & 32 & 73 \\
\hline & & $\begin{array}{l}\% \\
\text { Total }\end{array}$ & $56.2 \%$ & $43.8 \%$ & $100.0 \%$ \\
\hline
\end{tabular}

\begin{tabular}{|c|c|c|c|c|}
\hline & $\mathbf{V}=\mathbf{5}$ & \multicolumn{2}{|c|}{ Are you satisfied from the working time of your duty? } & \multirow[t]{2}{*}{ Total } \\
\hline & & Yes & No & \\
\hline \multirow[t]{2}{*}{ Male } & Count & 6 & 10 & 16 \\
\hline & $\%$ of Total & $8.2 \%$ & $13.7 \%$ & $21.9 \%$ \\
\hline \multirow{2}{*}{ Female } & Count & 46 & 11 & 57 \\
\hline & $\%$ of Total & $63.0 \%$ & $15.1 \%$ & $78.1 \%$ \\
\hline \multirow[t]{2}{*}{ Total } & Count & 52 & 21 & 73 \\
\hline & $\%$ of Total & $71.2 \%$ & $28.8 \%$ & $100.0 \%$ \\
\hline
\end{tabular}

\section{Discussion}

The respondent rate in this study was $91 \%$. The total number of sample was 80 (which were calculated through Raosoft calculator) in which 73 respondents respond, in these 73 respondents 57 were female and 16 were male. The overall result of this study is good.83\% respondent were satisfied from their job.

The job satisfaction levels of nurses were positive, means majority were satisfied from their job by asking questions through questionnaire in this study. Out of total 5 
variable in four the 'Yes' response is more than $50 \%$ and in one variable the respondent rate was high in "No" response so we can say that overall $80 \%$ respondent satisfied from job. The overall ratio among male and female show that female were more satisfied as compared to male as their ratio is also high than male in number. Majority $(52.1 \%)$ of the respondents were age between 26 to 30 (table 2). Only 3 respondent ages above 35. (Table 2). In variable no 1 table no 3 show that out of 73 respondents $61(83.6 \%)$ were reply that they are satisfied from their current job. Only $16.4 \%$ were reply that they are not satisfied from their job. In variable 2, when asked about current salary, most of the respondents were agree from current salary given to them. About $64.4 \%$ among total respondent (73) were satisfied from current salary. Salary has great impact on job satisfaction and retention of employee in an organization. Among male respondent only 1 had unsatisfied from the pay which has given to them. Good pay/salary directly affect employee's retention status and satisfaction. One of the study from Karachi in 2013 suggest that healthcare professionals must be given attractive compensation

Job security is very much important because the employee has a tension that at any stage organization may terminate the contract of any employee because of job insecurity. So if the organization given some of the security about job the employee will happy and worked with full concentration. In this regard those people that are working in government hospital are more happy/stable as compared to private.

In this current research only $36 \%$ of respondent were satisfied from job about security, 37\% were answer that they are not satisfied from job security means that they had fear that their job is not secure, among which male has very low satisfaction (table-5) Working hours/time is also affect job satisfaction because in nursing field majority are female and they have (female) so many problems, transportation, hostel, family, children etc, so this study show that $52 \%$ (table 7) were satisfied from the current working time, among which female were more satisfied as compared to male. In service education/ training is also one of the major thing/ tools for employees which have a good and positive effect in delivering care to the patient. When asking about training 565 respondents agree that hospital provide them some sort of training, among these majority of male has reply know that there is no training given to them.

\section{CONClusion}

From this study it is concluded that most of the nurses were satisfied from their job, salary and working hours/time but the job security is one of the issue, nurses has a fear that their job is not secure any time he/she can be relieve from their job.in Khyberpukhtunkhwa government there is a dual health system started from 2015, the old system in which all the employees were under the supervision of health department KPK but from 2015, an act which called Medical Teaching Institution (MTI) Act 2015, was passed from Provincial assembly KPK in which some Teaching hospital were become MTI(independent) these hospital become autonomous in financial, employees matter. They select the people as an MTI employee for a short period of time (2-3 year) not as permanent, so employee become confused and has a fear of job insecurity.

\section{RECOMMENDATION}

The government as well as MTI ensure job security of employees and also compensation of employees This thing will bring more positive result because when the employee is happy and satisfied the result will be better.

\section{REFERENCES}

[1] www.google.com.pk/dictionary.cambridge.org

[2] F Marcia. Survey of Registered Nurses conducted by AMN Healthcare web blog Available from http://www.rn.com/nursingnews/nursing-career-satisfaction-vs-jobsatsatisfaction [Accessed: 22th May 2017].

[3] Al Maqbali MA.Factors that influence nurses' job satisfaction: a literature review. Nurs Manag (Harrow). 2015 May; 22(2):30-7. doi: 10.7748/nm.22.2.30.e129.

[4] Maslow AH: Motivation and Personality. 5thed, New York, Harper; 1954.

[5] Herzberg F, Mausner B: The motivation of work.2nded. New York; 1959.

[6] Khan A, Nawaz M. Aleem M. and Hamed W. Impact of job satisfaction on employee performance: An empirical study of autonomous Medical Institutions of Pakistan. African J of Business Management Vol. 6 (7), 2012; pp. 269 7-2705, 22.

[7] ZahajM.,SaliaAj.,MetaniL.,NikaS.,AlushiEFact ors related to job satisfaction among Nurses. European Scientific Journal.12.2016; 1857 7881

[8] Lorber $M$ and SavičB.S. Job satisfaction of nurses and identifying factors of job Satisfaction in Slovenian Hospitals. Croat Med J. 2012 Jun; 53(3): 263-270. 
[9] BahalkaniH.A,KumarR,Lakho A.R, Mahar B,Mazhar S.B,Majeed A.Job satisfaction innurses working in tertiary level health care settings of islamabad, Pakistan.AyubMedical College Journal.2011;23(3).

[10] Naveed I,Hussain A, Sarfraz M, fghan S, WaqarS.H. Assessment of Job Satisfaction among Nurses working in Children Hospital, Pakistan Institute of Medical Sciences, Islamabad. Pak J Med Res (2016); Vol. 55, No. 4.

[11] Dar I.S, Ahsan-ul-Haq M, Quratulain..Factors influencing job satisfaction of nurses in public hospitals.Sci.Int.(Lahore) (2015) 27(3), 17611765

[12] Jaiswal P, Gadpayle A K, Singhal AK, Sachdeva S, Modi RK, Padaria R, Ravi V. Job Satisfaction among hospital staff working in a Government teaching hospital of India. Med J DY PatilUniv [serial online] 2015 [cited 2017
Mar 9]; 8:131-7. Available from: http://www. mjdrdypu.org/text.asp?2015/8/2/131/153136

[13] Zahaj M. Saliaj A. MetaniL.Nikan S, Alushi E. Factors Related To Job Satisfaction Among Nurses,European Scientific Journal February 2016 edition vol.12, No.5 ISSN: $1857-7881$ (Print) e - ISSN 1857- 7431

[14] Wang Y,Dong W , Mauk K, Li P, Wang J, Yang G,FangL,Huau W, HaoM.Nurses' Practice Environment and Their Job Satisfaction: A Study on Nurses Caring for Older Adults in Shanghai. (2015) PLoSONE 10(9): e0138035. https://doi.org/10.1371/ journal. pone. 0138035

[15] Department of health Khyber Pakhtunkhwa (KPK) act 2015 available from webpage www.healthkp.gov.pk [accessed 30 March 2017].

Citation: Abdullah, Fatheur Rahman, Hassan Ali, Javid Iqbal, Job Satisfaction among Nurses Working Medical Teaching Institutions Khyber Pakhtunkhw, ARC Journal of Nursing and Healthcare. 2019; 5(4):8-12. doi: dx.doi.org/ 10.20431/2455-4324.0504002.

Copyright: (c) 2019 Authors. This is an open-access article distributed under the terms of the Creative Commons Attribution License, which permits unrestricted use, distribution, and reproduction in any medium, provided the original author and source are credited. 